U.S. Department of the Interior

U.S. Geological Survey

Human-Health Pharmaceutical Compounds in Lake Mead, Nevada and Arizona, and Las Vegas Wash, Nevada, October 2000-August 2001

Open-File Report 02-385

Prepared in cooperation with the

U.S. DEPARTMENT OF THE INTERIOR, NATIONAL PARK SERVICE

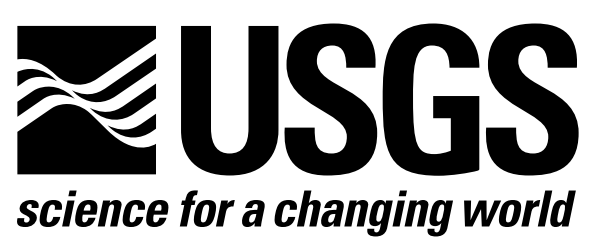


(Back of Cover) 


\title{
Human-Health Pharmaceutical Compounds in Lake Mead, Nevada and Arizona, and Las Vegas Wash, Nevada, October 2000-August 2001
}

\author{
By Robert A. Boyd and Edward T. Furlong
}

U.S. GEOLOGICAL SURVEY

Open-File Report 02-385

Carson City, Nevada 


\title{
U.S. DEPARTMENT OF THE INTERIOR GALE A. NORTON, Secretary
}

\author{
U.S. GEOLOGICAL SURVEY \\ CHARLES G. GROAT, Director
}

Any use of trade, product, or firm names in this publication is for descriptive purposes only and does not imply endorsement by the U.S. Government

For additional information contact:

District Chief

U.S. Geological Survey 333 West Nye Lane, Room 203

Carson City, NV 89706-0866

email: GS-W-NVpublic-info@usgs.gov

URL: http://nevada.usgs.gov 


\section{CONTENTS}

Abstract

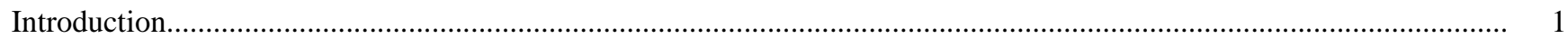

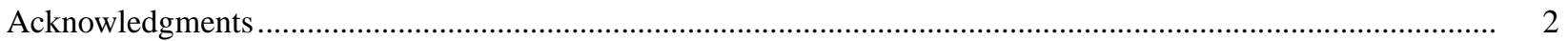

Description of Study Area .........................................................................................................................

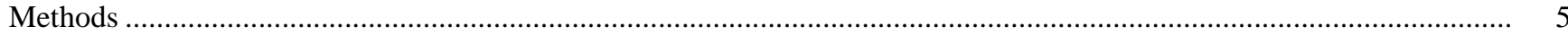

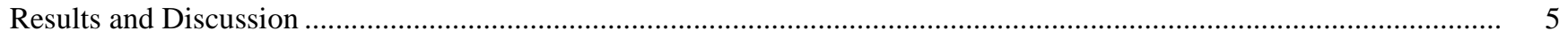

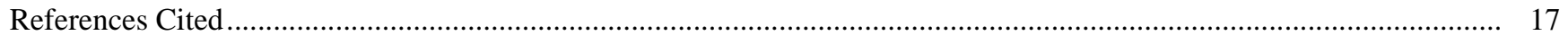

\section{FIGURES}

1. Map showing study area and sample-collection sites, Lake Mead, Nevada and Arizona, and Las Vegas Wash, Nevada, October 2000-August 2001

2. Graph showing mean daily streamflow in Las Vegas Wash, Nevada, and dates of sample collection for human-health pharmaceutical compounds, October 2000-August 2001.

3. Bar plot showing summary of human-health pharmaceutical compounds detected in water samples collected from Lake Mead, Nevada and Arizona, and Las Vegas Wash, Nevada, October 2000-August 2001

4. Plots showing physical properties measured at sample-collection sites for analyses of human-health pharmaceutical compounds, Lake Mead, Nevada and Arizona, and Las Vegas Wash, Nevada,

October 2000-August 2001

\section{TABLES}

1. Human-health pharmaceutical compounds targeted by chemical analyses of water samples collected from Lake Mead, Nevada and Arizona, and Las Vegas Wash, Nevada, October 2000-August 2001

2. Information for sites used to collect water samples for analyses of human-health pharmaceutical compounds, Lake Mead, Nevada and Arizona, and Las Vegas Wash, Nevada, October 2000-August 2001 ........

3. Summary of human-health pharmaceutical compound concentrations detected in water samples collected from Lake Mead, Nevada and Arizona, and Las Vegas Wash below Lake Las Vegas, Nevada, October 2000-August 2001

4. Human-health pharmaceutical compound concentrations in water samples collected from Lake Mead, Nevada and Arizona, and Las Vegas Wash, Nevada, October 2000-August 2001

5. Physical properties measured concurrently with water samples collected for analyses of human-health pharmaceutical compounds, Las Vegas Wash below Lake Las Vegas, Nevada, October 2000-August 2001 


\section{CONVERSION FACTORS AND VERTICAL DATUM}

\begin{tabular}{rll}
\hline Multiply & By & To obtain \\
\hline inch (in.) & 25.4 & millimeter \\
foot (ft) & 0.3048 & meter \\
mile (mi) & 1.609 & kilometer \\
square mile $\left(\mathrm{mi}^{2}\right)$ & 2.590 & square kilometer \\
cubic foot per second $\left(\mathrm{ft}^{3} / \mathrm{s}\right)$ & 0.02832 & cubic meter per second \\
fluid ounce $(\mathrm{oz})$ & 29.57 & milliliter \\
\hline
\end{tabular}

Temperature: Degrees Celsius $\left({ }^{\circ} \mathrm{C}\right)$ can be converted to degrees Fahrenheit $\left({ }^{\circ} \mathrm{F}\right)$ by using the formula ${ }^{\circ} \mathrm{F}=\left[1.8\left({ }^{\circ} \mathrm{C}\right)\right]+32$. Degrees Fahrenheit can be converted to degrees Celsius by using the formula ${ }^{\circ} \mathrm{C}=0.556\left({ }^{\circ} \mathrm{F}-32\right)$.

Sea level: In this report, "sea level" refers to the National Geodetic Vertical Datum of 1929 (NGVD of 1929, formerly called "Sea-Level Datum of 1929"), which is derived from a general adjustment of the first-order leveling networks of the United States and Canada.

Abbreviation of water-quality units used int is report:

L, liter

$\mathrm{mL}$, milliliter

$\mu \mathrm{m}$, micrometer

$\mathrm{mg} / \mathrm{L}$, milligrams per liter

$\mu \mathrm{g} / \mathrm{L}$, micrograms per liter

$\mu \mathrm{S} / \mathrm{cm}$, microsiemens per centimeter at 25 degrees Celsius

\section{Explanation of water-quality units:}

Milligrams per liter express the concentration of chemical constituents in solution as weight (in milligrams) of solute per unit volume (liter) of water. Micrograms per liter expresses the concentration of chemical constituents in solution as weight (in micrograms) of solute per unit volume (liter) of water. Microsiemens per centimeter expresses the capability of a unit volume of water to conduct an applied electrical current. 


\title{
Human-Health Pharmaceutical Compounds in Lake Mead, Nevada and Arizona, and Las Vegas Wash, Nevada, October 2000-August 2001
}

\author{
By Robert A. Boyd and Edward T. Furlong
}

\section{ABSTRACT}

The U.S. Geological Survey and the National Park Service conducted a reconnaissance study to investigate the occurrence of selected human-health pharmaceutical compounds in water samples collected from Lake Mead on the Colorado River and Las Vegas Wash, a waterway used to transport treated wastewater from the Las Vegas metropolitan area to Lake Mead. Current research indicates many of these compounds can bioaccumulate and may adversely affect aquatic organisms by disrupting physiological processes, impairing reproductive functions, increasing cancer rates, contributing to the development of antibiotic-resistant strains of bacteria, and acting in undesirable ways when mixed with other substances. These compounds may be present in effluent because a high percentage of prescription and non-prescription drugs used for human-health purposes are excreted from the body as a mixture of parent compounds and degraded metabolite compounds; also, they can be released to the environment when unused products are discarded by way of toilets, sinks, and trash in landfills.

Thirteen of 33 targeted compounds were detected in at least one water sample collected between October 2000 and August 2001. All concentrations were less than or equal to 0.20 micrograms per liter. The most frequently detected compounds in samples from Las Vegas Wash were caffeine, carbamazepine (used to treat epilepsy), cotinine (a metabolite of nicotine), and dehydronifedipine (a metabolite of the antianginal Procardia). Less frequently detected compounds in samples collected from Las Vegas Wash were antibiotics (clarithromycin, erythromycin, sulfamethoxazole, and trimethoprim), acetaminophen (an analgesic and anti-inflammatory), cimetidine (used to treat ulcers), codeine (a narcotic and analgesic), diltiazem (an antihypertensive), and 1,7-dimethylxanthine (a metabolite of caffeine). Fewer compounds were detected in samples collected from Lake Mead than from Las Vegas Wash. Caffeine was detected in all samples collected from Lake Mead. Other compounds detected in samples collected from Lake Mead were acetaminophen, carbamazepine, cotinine, 1,7-dimethylxanthine, and sulfamethoxazole.

\section{INTRODUCTION}

Modern society has developed numerous synthetic organic compounds with a variety of applications to maintain and improve a relative high-quality lifestyle. Prescription and non-prescription pharmaceutical compounds are used to treat human-health medical conditions and diseases. Veterinary pharmaceuticals and hormonal growth stimulators are used to increase meat and dairy production. Pesticides are applied to cropland to help improve agricultural productivity. Personal-care products, household chemicals, and inert ingredients in consumer products are used to provide daily conveniences in our lives. Industrial chemicals and byproducts make manufacturing processes more efficient. Although synthetic organic compounds are used for many beneficial purposes, increasing evidence indicates that many of these compounds are released to the environment and may have harmful effects on aquatic ecosystems. 
Prescription and non-prescription pharmaceutical compounds are of particular concern because they are formulated to have biological effects in human receptors. Many of these compounds are lipophilic, readily dissolving in fatty tissue but not in water, and can bioaccumulate or biomagnify in aquatic or terrestrial organisms (Halling-Sorensen and others, 1998). Little is known about the potential effects on humans and biota resulting from environmental exposure to such compounds. Ongoing research indicates there may be chronic effects from long-term exposure to very low concentrations of some compounds. Potential effects include abnormal physiological processes, impaired reproductivity, increased cancer rates, development of antibiotic-resistant strains of bacteria, disruption of bacterial beds used to purify wastewater in many treatment plants, and acting in undesirable ways when mixed with other substances (Kolpin and others, 2002; Halling-Sorensen and others, 1998).

Large quantities of pharmaceuticals are used annually to treat and cure diseases and medical conditions. Some of these compounds consumed by humans are excreted by the body as a mixture of parent compounds and metabolites. These compounds are transported with human wastes to municipal wastewatertreatment or domestic septic systems and can be discharged with effluent to the environment. Compounds also can be released when unused products are discarded by way of toilets, sinks, and trash in landfills.

Few studies have addressed the occurrence, fate, or transport of human-health pharmaceutical compounds in the environment. The release of pharmaceutical compounds with wastewater effluent to the environment was first identified in the 1970s by Hignite and Azarnoff (1977). Not until the 1990s were issues relating to the release of these compounds researched because few analytical techniques existed with sufficient sensitivity to detect these compounds at very low concentrations (micrograms per liter or less). HallingSorensen and others (1998) and Daughton and Ternes (1999) summarize the chemical properties of pharmaceutical compounds and associated known and suspected ecotoxicological effects. Results reported by Snyder and others (1999), Seiler and others (1999), Barnes and others (2002), and Kolpin and others (2002) indicate an increasing number of compounds are being detected in waters receiving wastewater effluents.
The U.S. Geological Survey (USGS) and National Park Service (NPS) conducted a reconnaissance study to assess the occurrence of selected humanhealth pharmaceutical compounds (table 1) in Lake Mead on the Colorado River in Nevada and Arizona and Las Vegas Wash, a waterway used to discharge treated effluent from the Las Vegas Valley to Lake Mead in Nevada. Additional samples were collected from Las Vegas Wash in cooperation with the Las Vegas Valley Water District.

\section{Acknowledgments}

The authors express appreciation to Jefferey Cahill of the USGS National Water Quality Laboratory for his expertise in conducting the chemical analyses of water samples. This study was made possible by funding provided through the NPS/USGS Water-Quality Partnership program. Funding for analyses of additional samples collected from Las Vegas Wash was provided by the Las Vegas Valley Water District as part of a cooperative program with the USGS.

\section{Description of Study Area}

Lake Mead is the largest freshwater reservoir (by volume) in the United States. In Nevada and Arizona, Lake Mead impounds the Colorado River behind Hoover Dam (fig. 1). The lake is an important source of water for more than 20 million people in southern Nevada, southern California, and Arizona. The lake supports economically important sport fisheries for striped bass (Morone saxatilis), largemouth bass (Micropterus salmoides), and channel catfish (Ictalurus punctatus) and provides habitat for the endangered razorback sucker (Xyrauchen texanus). The waters and adjacent riparian habitats of the lake also support large numbers of birds.

NPS provides stewardship of the lake's natural resources as part of the Lake Mead National Recreation Area. Lake Mead and surrounding land provide recreational activities such as boating, fishing, and camping to more than 10 million people each year. Several small marina facilities and boat ramps around the lake support these activities. Visitors to Lake Mead are greatest in number during summer months and Boulder Basin is the most visited area. 
Table 1. Human-health pharmaceutical compounds targeted by chemical analyses of water samples collected from Lake Mead, Nevada and Arizona, and Las Vegas Wash, Nevada, October 2000-August 2001

[--, Laboratory reporting limit not determined. All concentrations are in micrograms per liter]

\begin{tabular}{|c|c|c|}
\hline Compound & Usage & $\begin{array}{l}\text { Laboratory } \\
\text { reporting limit }\end{array}$ \\
\hline Acetaminophen & Analgesic; anti-inflammatory & 0.009 \\
\hline Amoxicillin & Antibiotic & -- \\
\hline Azithromycin & Antibiotic & -- \\
\hline Caffeine & Stimulant & 0.014 \\
\hline Carbamazepine & Antiepileptic; analgesic & -- \\
\hline Cephalexin & Antibiotic & -- \\
\hline Cimetidine & Antiulcerant; stomach-acid reducer & 0.007 \\
\hline Clarithromycin & Antibiotic & -- \\
\hline Codeine & Narcotic; analgesic & 0.024 \\
\hline Cotinine & Metabolite of nicotine & 0.023 \\
\hline Dehydronifedipine & Metabolite of Procardia (vasodilator) & 0.01 \\
\hline Digoxigenin & Metabolite of Digoxin (antianginal) & 0.008 \\
\hline Digoxin & Antianginal (cardiac stimulant) & 0.26 \\
\hline Diltiazem & Antianginal & 0.012 \\
\hline 1,7-dimethylxanthine & Metabolite of caffeine & 0.018 \\
\hline Diphenhydramine & Antihistamine & -- \\
\hline Enalaprilat & Antihypertensive & 0.152 \\
\hline Erythromycin & Antibiotic & 0.05 \\
\hline Fluoxetine & Antidepressant & 0.018 \\
\hline Furosemide & Edema medication; diuretic & -- \\
\hline Gemfibrozil & Cholesterol regulator & 0.015 \\
\hline Ibuprofen & Analgesic; anti-inflammatory & 0.018 \\
\hline Lisinopril & Antihypertensive & -- \\
\hline Metformin & Antiglycemic & 0.003 \\
\hline Miconazole & Antifungal & -- \\
\hline Paroxetine metabolite & Metabolite of Paroxetine (antianxiety) & 0.26 \\
\hline Ranitidine & Antiulcerant; antacid & 0.01 \\
\hline Salbutamol (albuterol) & Anti-inflammatory; bronchodilator & 0.029 \\
\hline Sulfamethoxazole & Antibiotic & 0.023 \\
\hline Thiabendazole & Anthelmintic (intestinal wormer) & -- \\
\hline Trimethoprim & Antibiotic & 0.014 \\
\hline Urobilin & Metabolite of human excrement & -- \\
\hline Warfarin & Anticoagulant & 0.001 \\
\hline
\end{tabular}




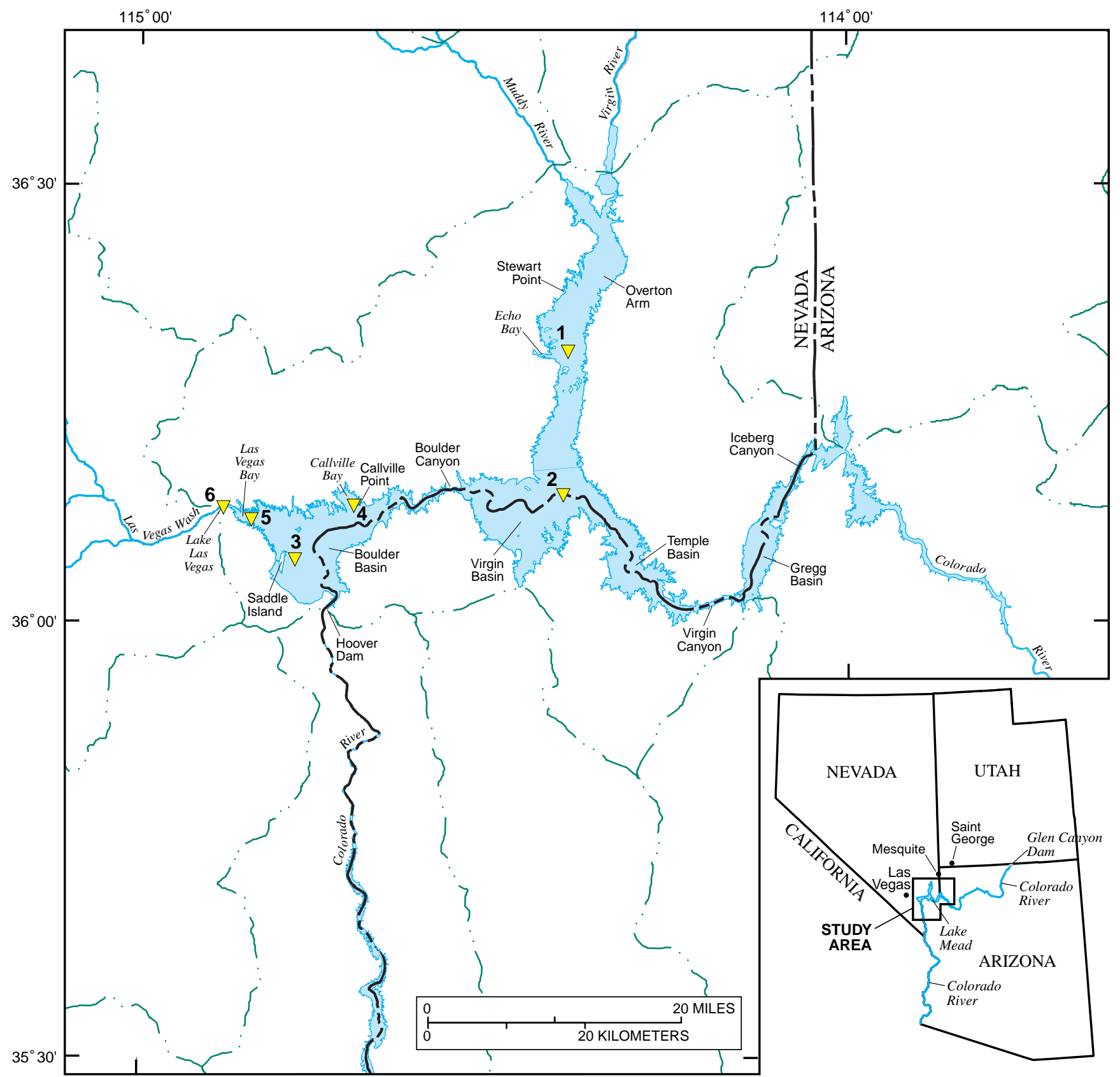

Base from U.S. Geological Survey digital data, 1:100,000-scale, 1987;

Universal Transverse Mercator Projection, Zone 11

EXPLANATION

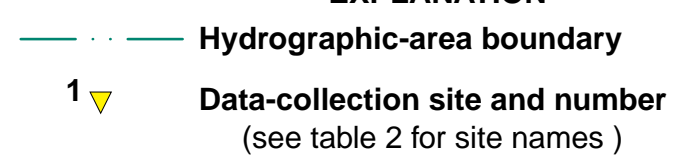

Figure 1. Study area and sample-collection sites, Lake Mead, Nevada and Arizona, and Las Vegas Wash, Nevada, October 2000-August 2001. 
The Colorado River provides about 97 percent of the total annual inflow to Lake Mead. The remaining inflows are from Las Vegas Wash (about 1.5 percent), the Virgin and Muddy Rivers (about 1.4 percent), and stormwater runoff from numerous ephemeral tributary washes (less than 0.1 percent). Upstream of Lake Mead, the Colorado River drains areas that generally are sparsely populated; much of the drainage area is undeveloped land, but land uses include rangeland, irrigated cropland, and mining (U.S. Department of Interior, 1999). Las Vegas Wash drains an area of about 2,200 $\mathrm{mi}^{2}$ and transports most treated municipal effluent, stormwater and urban runoff, and ground-water seepage from the Las Vegas metropolitan area to Las Vegas Bay of Boulder Basin on Lake Mead (fig. 1). Treated municipal effluent is about 80 percent of the water discharged from Las Vegas Wash to Lake Mead (Las Vegas Valley Water District, 2002). LaBounty and Horn (1997) summarized previous studies and reported that water discharged by Las Vegas Wash degrades water quality in Las Vegas Bay and parts of Boulder Basin. The Virgin and Muddy Rivers discharge into the Overton Arm of Lake Mead (fig. 1). The Virgin and Muddy Rivers drain large areas of undeveloped land with some irrigated cropland. Rapidly developing areas in Mesquite, Nevada, and St. George, Utah, discharge treated municipal wastewater effluent to the Virgin River.

The local climate near Lake Mead is arid to semiarid. The average annual rainfall is about 4 in. Most rainfall occurs from December through March, although thunderstorms of short duration and high intensity do occur in summer months. Air temperatures in summer months typically exceed $100^{\circ} \mathrm{F}$ and in winter months are about $60^{\circ} \mathrm{F}$ (Covay and others, 1996).

\section{METHODS}

Water samples for chemical analyses were collected at five sites on Lake Mead and one site on Las Vegas Wash (fig.1; table 2). Samples were collected in March 2001 and August 2001 to evaluate seasonal variation in compound occurrence and concentrations. A replicate field sample and equipment blank were collected with each set of samples collected from Lake Mead. Several additional samples were collected from Las Vegas Wash at various times of the year (fig. 2). Methods used to collect water samples are described in Wilde and others (1998).
Samples of lake water were collected with a stainless-steel Kemmerer bottle with Teflon seals from a depth of $25 \mathrm{ft}$ below water surface. The Kemmerer bottle was cleaned between sampling sites with phosphate-free detergent and rinsed with reagent-grade deionized water. Samples were collected from Las Vegas Wash by submerging a 1-L, baked amber-glass sample bottle beneath the water surface in a well-mixed part of the stream near the center of the channel. Water samples were filtered through a $0.7-\mu \mathrm{m}$ pore-size, baked glass-fiber filter into 1-L, baked amber-glass bottles. Samples were chilled and shipped by express mail to the USGS National Water Quality Laboratory. Water temperature, specific conductance, $\mathrm{pH}$, and dissolved oxygen were measured at the time of sample collection with a multiprobe instrument at discrete depths at the Lake Mead sample sites and with portable instruments at the Las Vegas Wash sample site.

Pharmaceutical compounds were extracted and concentrated from water samples using polymeric hydrophilic-lipophylic balance solid-phase extraction cartridges. Adsorbed compounds were eluted from the cartridges with methanol followed by methanol acidified with trichloroacetic acid. The two fractions were reduced under nitrogen gas and then combined and brought to a final volume of $1 \mathrm{~mL}$ in a solution of 10 percent acetonitrile and 90 percent water buffered with ammonium peroxide/formic acid (Kolpin and others, 2002).

Sample extracts were analyzed with reversedphase, high-performance liquid chromatography/electrospray ionization-mass spectrometry. Selected-ion monitoring was used to reduce signal noise and enhance sensitivity. Specificity was optimized by using insource fragmentation to generate three diagnostic fragment ions from the parent compound. Laboratory method-blank samples, method-spike samples, and method-performance surrogates were used for internal quality control (Kolpin and others, 2002).

\section{RESULTS AND DISCUSSION}

Human-health pharmaceutical compounds detected in water samples collected from Lake Mead and Las Vegas Wash are summarized in figure 3 and table 3. Results of chemical analyses of water samples collected from Lake Mead and Las Vegas Wash are listed in table 4. Depth profiles of physical properties measured at sample-collection sites on Lake Mead are 
Table 2. Information for sites used to collect water samples for analyses of human-health pharmaceutical compounds, Lake Mead, Nevada and Arizona, and Las Vegas Wash, Nevada, October 2000-August 2001

[Latitude and longitude referenced to North American Datum of 1927; lake elevations correspond to week of sample collection and were obtained from the Bureau of Reclamation, electronic data accessed at www.usbr.gov on May 29, 2002]

\begin{tabular}{|c|c|c|c|c|c|}
\hline \multirow{2}{*}{$\begin{array}{l}\text { Site } \\
\text { number } \\
\text { (see } \\
\text { fig. 1) }\end{array}$} & \multirow{2}{*}{ Site name } & \multirow{2}{*}{ Latitude } & \multirow{2}{*}{ Longitude } & \multicolumn{2}{|c|}{$\begin{array}{l}\text { Lake elevation, } \\
\text { in feet above sea level }\end{array}$} \\
\hline & & & & $\begin{array}{c}\text { March } \\
2001\end{array}$ & $\begin{array}{l}\text { August } \\
2001\end{array}$ \\
\hline 1 & Lake Mead at Echo Bay & $36^{\circ} 18^{\prime} 48^{\prime \prime}$ & $114^{\circ} 23^{\prime} 38^{\prime \prime}$ & 1,196 & 1,180 \\
\hline 2 & Lake Mead near historic confluence of Colorado and Virgin Rivers & $36^{\circ} 09^{\prime} 12^{\prime \prime}$ & $114^{\circ} 23^{\prime} 52^{\prime \prime}$ & 1,196 & 1,180 \\
\hline 4 & Lake Mead at Callville Bay near Callville Point & $36^{\circ} 07^{\prime} 42^{\prime \prime}$ & $114^{\circ} 43^{\prime} 29^{\prime \prime}$ & 1,196 & 1,180 \\
\hline 5 & Lake Mead at Las Vegas Bay C-Buoy & $36^{\circ} 07^{\prime} 43^{\prime \prime}$ & $114^{\circ} 51^{\prime} 58^{\prime \prime}$ & 1,196 & 1,180 \\
\hline 6 & Las Vegas Wash below Lake Las Vegas & $36^{\circ} 07^{\prime} 14^{\prime \prime}$ & $114^{\circ} 54^{\prime} 34^{\prime \prime}$ & NA & NA \\
\hline
\end{tabular}

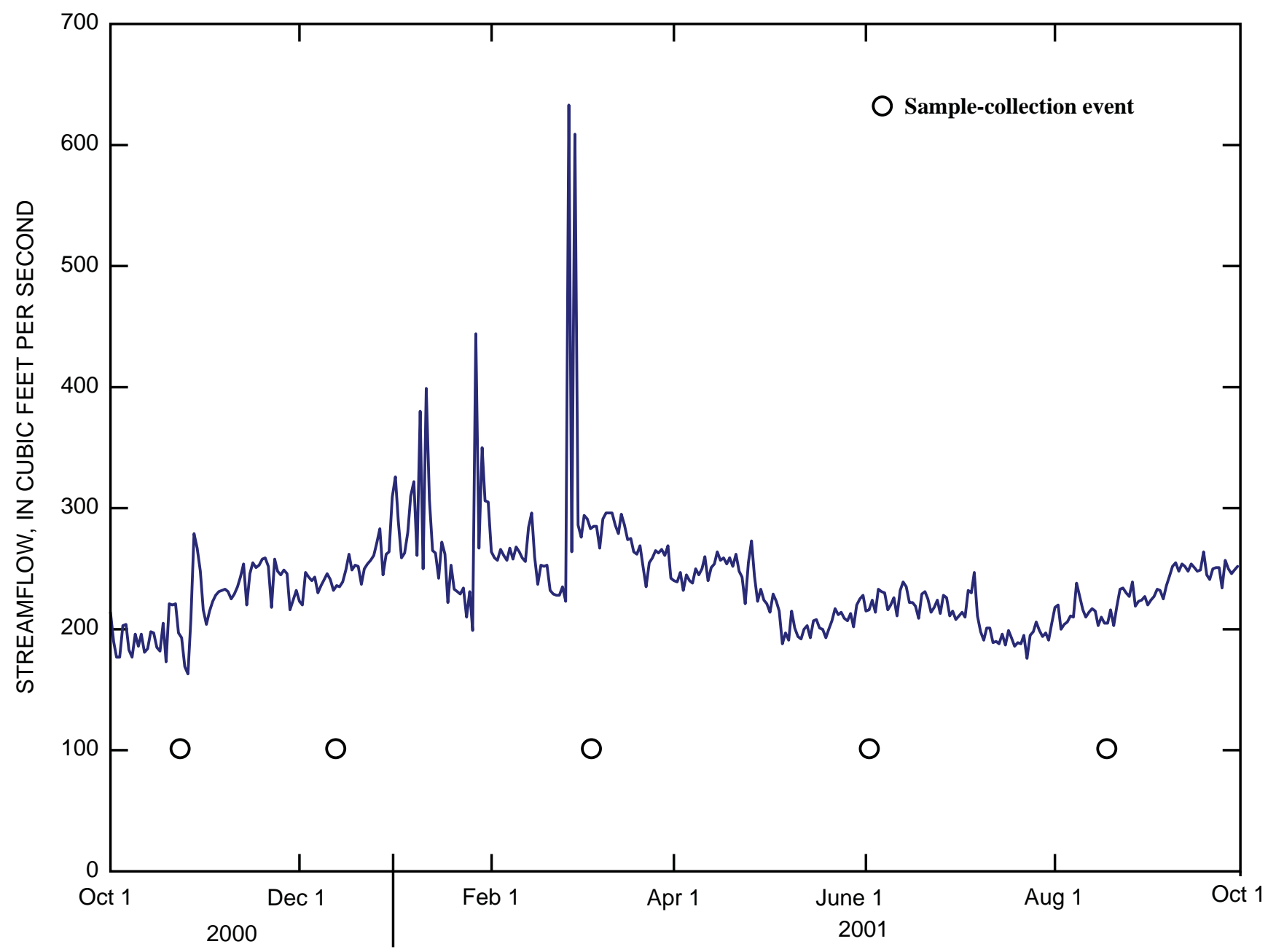

Figure 2. Mean daily streamflow in Las Vegas Wash, Nevada, and dates of sample collection for human-health pharmaceutical compounds, October 2000-August 2001.

6 Human-Health Pharmaceutical Compounds in Lake Mead, Nevada and Arizona, and Las Vegas Wash, Nevada, Oct. 2000-Aug. 2001 


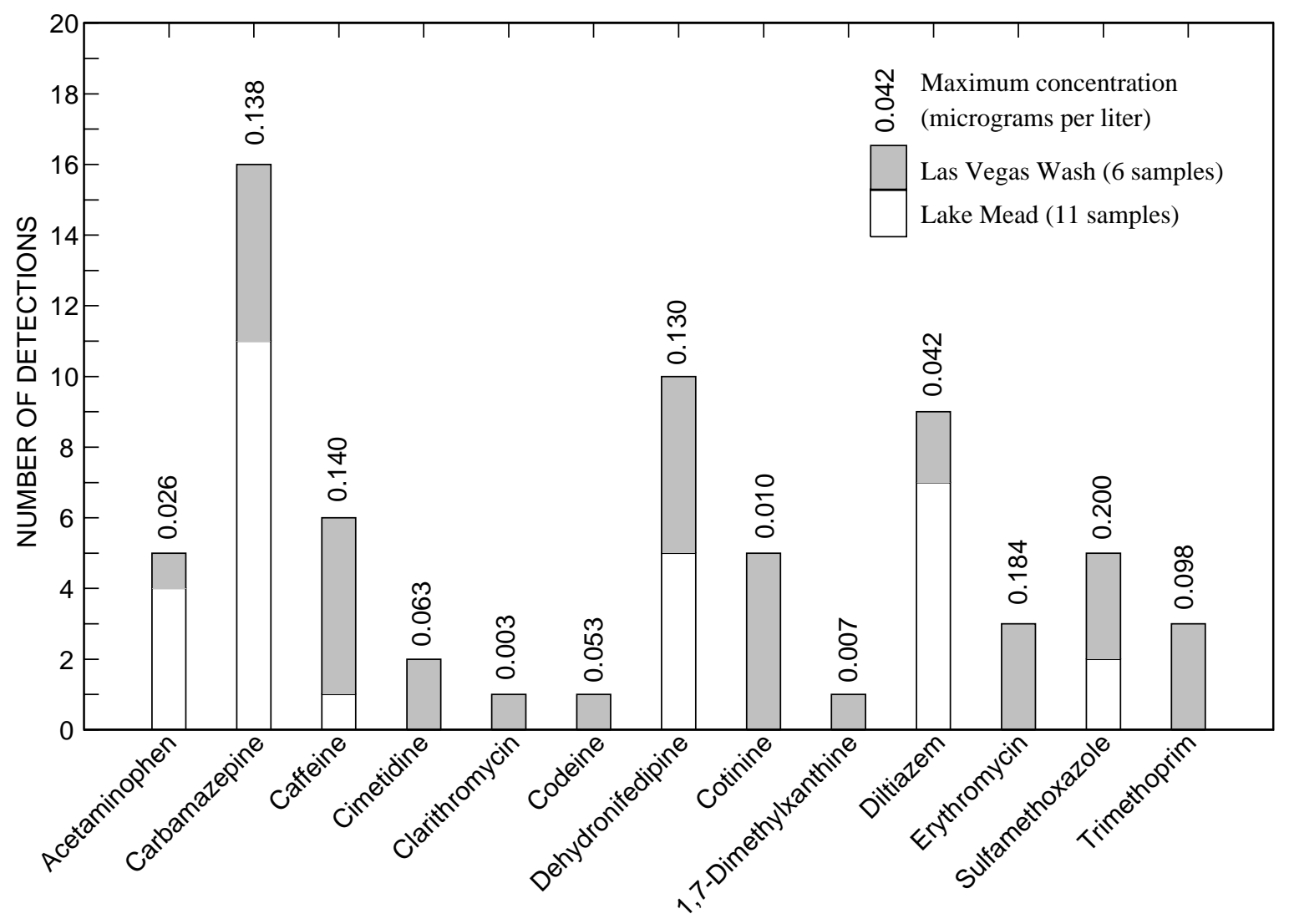

Figure 3. Summary of human-health pharmaceutical compounds detected in water samples collected from Lake Mead, Nevada and Arizona, and Las Vegas Wash, Nevada, October 2000-August 2001.

shown in figure 4 and at Las Vegas Wash in table 5. Thirteen of 33 targeted compounds were detected at least once in samples collected between October 2000 and August 2001. Concentrations were small; all were less than or equal to $0.20 \mu \mathrm{g} / \mathrm{L}$.

Caffeine, cotinine, and 1,7-dimethylxanthine were the most frequently detected compounds (table 3 ). These compounds primarily are associated with the consumption of caffeinated beverages, the use of tobacco products, and the use of nonprescription dieting aids and appetite suppressants, respectively. Caffeine concentrations detected in some samples may be greater than ambient environmental concentrations because caffeine was detected in both equipment-blank samples. Determining how many samples were affected by caffeine contamination was not possible because only one equipment-blank sample was collected with each set of samples to evaluate the cleanliness of equipment and materials used to collect and process water samples. Possible sources of caffeine contamination included personnel who collected and processed water samples, deionized water and detergent used to clean and rinse sampling equipment, and organic-free deionized water used to collect the equipment-rinse sample. Caffeine was not detected in internal laboratory-blank samples analyzed for laboratory quality control. Other frequently detected compounds included acetaminophen (an analgesic), carbamazepine (used to treat epilepsy), and antibiotics (clarithromycin, eryhtromycin, sulfamethoxazole, and trimethoprim).

All 13 of the detected compounds occurred in at least one sample collected from Las Vegas Wash. Caffeine and cotinine were detected in five of six water samples. Caffeine has been associated with wastewater discharges for many years as reported in Rogers and others (1986), Buszka and others (1994), Blomquist and others (2001), and Seiler and others (1999). Most detections of prescription-pharmaceutical compounds occurred in samples collected from Las Vegas Wash. Antibiotics were the most frequently detected class of compounds with clarithromycin, erythromycin, sulfamethoxazole, and trimethoprim detected in one or 
Table 3. Summary of human-health pharmaceutical compound concentrations detected in water samples collected from Lake Mead, Nevada and Arizona, and Las Vegas Wash below Lake Las Vegas, Nevada, October 2000-August 2001

[Abbreviations: Freq., frequency of detection; Min., minimum concentration; Max., maximum concentration; <, less than indicated laboratory reporting limit; --, not applicable; e, estimated concentration less than laboratory reporting limit; ND, not detected at concentration greater than laboratory reporting limit (reporting limit not determined).

All concentrations are in micrograms per liter]

\begin{tabular}{|c|c|c|c|c|c|c|c|c|c|c|c|c|}
\hline \multirow{3}{*}{ Compound } & \multicolumn{6}{|c|}{ Lake Mead (sites 1-5; see fig. 1) } & \multirow{2}{*}{\multicolumn{6}{|c|}{ Las Vegas Wash below Lake Las Vegas (site 6; see fig. 1) }} \\
\hline & \multicolumn{3}{|c|}{ March 2001} & \multicolumn{3}{|c|}{ August 2001} & & & & & & \\
\hline & Freq. & Min. & Max. & Freq. & Min. & Max. & $10 / 24 / 00$ & $12 / 19 / 00$ & 03/04/01 & $06 / 05 / 01$ & $08 / 24 / 01$ & $08 / 24 / 01$ \\
\hline Acetaminophen & $4 / 6$ & $<0.009$ & 0.012 & $0 / 5$ & -- & -- & $<0.009$ & $<0.009$ & 0.026 & $<0.009$ & $<0.009$ & $<0.009$ \\
\hline Caffeine & $6 / 6$ & $.002 \mathrm{e}$ & .032 & $5 / 5$ & $0.006 \mathrm{e}$ & 0.138 & .130 & .090 & .040 & .056 & .020 & $<.014$ \\
\hline Carbamazepine & $0 / 6$ & -- & -- & $1 / 5$ & ND & .002 & ND & .064 & .052 & .140 & .087 & .032 \\
\hline Cimetidine & $0 / 6$ & -- & -- & $0 / 5$ & -- & -- & $<.007$ & .024 & .063 & $<.007$ & $<.007$ & $<.007$ \\
\hline Clarithromycin & $0 / 6$ & -- & -- & $0 / 5$ & -- & -- & ND & ND & .003 & ND & ND & ND \\
\hline Codeine & $0 / 6$ & -- & -- & $0 / 5$ & -- & -- & $<.024$ & $<.024$ & $<.024$ & .053 & $<.024$ & $<.024$ \\
\hline Cotinine & $0 / 6$ & -- & -- & $5 / 5$ & $.003 \mathrm{e}$ & $.016 \mathrm{e}$ & .130 & $<.023$ & $.014 \mathrm{e}$ & $.019 \mathrm{e}$ & .046 & .030 \\
\hline Dehydrodenifedipine & $0 / 6$ & -- & -- & $0 / 5$ & -- & -- & $<.01$ & $.0004 \mathrm{e}$ & .010 & .004 & $.003 \mathrm{e}$ & $.005 \mathrm{e}$ \\
\hline Diltiazem & $0 / 6$ & -- & -- & $0 / 5$ & -- & -- & $<.012$ & $<.012$ & $<.012$ & $.007 \mathrm{e}$ & $<.012$ & $<.012$ \\
\hline 1,7-dimethylxanthine & $5 / 6$ & $<.018$ & .042 & $2 / 5$ & $<.018$ & .021 & $<.018$ & $<.018$ & $<.018$ & .021 & $<.018$ & $.008 \mathrm{e}$ \\
\hline Erythromycin & $0 / 6$ & -- & -- & $0 / 5$ & -- & -- & $<.05$ & .097 & $<.05$ & .184 & .120 & $<.05$ \\
\hline Sulfamethoxazole & $0 / 6$ & -- & -- & $2 / 5$ & $<.023$ & .030 & $<.023$ & .149 & .200 & .073 & $<.023$ & $<.023$ \\
\hline Trimethoprim & $0 / 6$ & -- & -- & $0 / 5$ & -- & -- & $<.014$ & .098 & .065 & .015 & $<.014$ & $<.014$ \\
\hline
\end{tabular}


Table 4. Human-health pharmaceutical compound concentrations in water samples collected from Lake Mead, Nevada and Arizona, and Las Vegas Wash, Nevada, October 2000-August 2001

[Abbreviations: <LRL, less than laboratory reporting limit; e, estimated concentration less than laboratory reporting limit; ND, not detected. All concentrations are in micrograms per liter. Laboratory reporting limits are listed in table 1 . Site locations are shown in figure 1]

\begin{tabular}{|c|c|c|c|c|}
\hline Compound & $\begin{array}{c}\text { Lake Mead at } \\
\text { Echo Bay } \\
\text { (site 1) }\end{array}$ & $\begin{array}{l}\text { Lake Mead near } \\
\text { historic confluence } \\
\text { of Colorado and } \\
\text { Virgin Rivers } \\
\text { (site 2) }\end{array}$ & $\begin{array}{l}\text { Lake Mead near } \\
\text { Saddle Island } \\
\text { (site 3) }\end{array}$ & $\begin{array}{l}\text { Lake Mead at } \\
\text { Callville } \\
\text { Bay near } \\
\text { Callville Point } \\
\text { (site 4) }\end{array}$ \\
\hline & $03 / 02 / 01$ & $03 / 02 / 01$ & 03/01/01 & 03/01/01 \\
\hline Acetaminophen & 0.012 & $<\mathrm{LRL}$ & $0.002 \mathrm{e}$ & 0.011 \\
\hline Amoxicillin & ND & ND & ND & ND \\
\hline Azithromycin & ND & ND & ND & ND \\
\hline Caffeine & $0.005 \mathrm{e}$ & $0.007 \mathrm{e}$ & 0.032 & $0.005 \mathrm{e}$ \\
\hline Carbamazepine & ND & ND & ND & ND \\
\hline Cephalexin & ND & ND & ND & ND \\
\hline Cimetidine & $<\mathrm{LRL}$ & $<\mathrm{LRL}$ & $<\mathrm{LRL}$ & $<\mathrm{LRL}$ \\
\hline Clarithromycin & ND & ND & ND & ND \\
\hline Codeine & $<\mathrm{LRL}$ & $<\mathrm{LRL}$ & $<\mathrm{LRL}$ & $<\mathrm{LRL}$ \\
\hline Cotinine & $<\mathrm{LRL}$ & $<\mathrm{LRL}$ & $<\mathrm{LRL}$ & $<\mathrm{LRL}$ \\
\hline Dehydronifedipine & $<\mathrm{LRL}$ & $<\mathrm{LRL}$ & $<\mathrm{LRL}$ & $<\mathrm{LRL}$ \\
\hline Digoxigenin & $<\mathrm{LRL}$ & $<\mathrm{LRL}$ & $<\mathrm{LRL}$ & $<\mathrm{LRL}$ \\
\hline Digoxin & $<\mathrm{LRL}$ & $<\mathrm{LRL}$ & $<\mathrm{LRL}$ & $<\mathrm{LRL}$ \\
\hline Diltiazem & $<\mathrm{LRL}$ & $<\mathrm{LRL}$ & $<\mathrm{LRL}$ & $<\mathrm{LRL}$ \\
\hline 1,7-dimethylxanthine & $0.012 \mathrm{e}$ & 0.019 & 0.042 & $<\mathrm{LRL}$ \\
\hline Diphenhydramine & ND & ND & ND & ND \\
\hline Enalaprilat & $<\mathrm{LRL}$ & $<\mathrm{LRL}$ & $<\mathrm{LRL}$ & $<\mathrm{LRL}$ \\
\hline Erythromycin & $<\mathrm{LRL}$ & $<\mathrm{LRL}$ & $<\mathrm{LRL}$ & $<\mathrm{LRL}$ \\
\hline Fluoxetine & $<\mathrm{LRL}$ & $<\mathrm{LRL}$ & $<\mathrm{LRL}$ & $<\mathrm{LRL}$ \\
\hline Furosemide & ND & ND & ND & ND \\
\hline Gemfibrozil & $<\mathrm{LRL}$ & $<\mathrm{LRL}$ & $<\mathrm{LRL}$ & $<\mathrm{LRL}$ \\
\hline Ibuprofen & $<\mathrm{LRL}$ & $<\mathrm{LRL}$ & $<\mathrm{LRL}$ & $<\mathrm{LRL}$ \\
\hline Lisinopril & ND & ND & ND & ND \\
\hline Metformin & $<\mathrm{LRL}$ & $<\mathrm{LRL}$ & $<\mathrm{LRL}$ & $<\mathrm{LRL}$ \\
\hline Miconazole & ND & ND & ND & ND \\
\hline Paroxetine metabolite & $<\mathrm{LRL}$ & $<\mathrm{LRL}$ & $<\mathrm{LRL}$ & $<\mathrm{LRL}$ \\
\hline Ranitidine & $<\mathrm{LRL}$ & $<\mathrm{LRL}$ & $<\mathrm{LRL}$ & $<\mathrm{LRL}$ \\
\hline Salbutamol (albuterol) & $<\mathrm{LRL}$ & $<\mathrm{LRL}$ & $<\mathrm{LRL}$ & $<\mathrm{LRL}$ \\
\hline Sulfamethoxazole & $<\mathrm{LRL}$ & $<\mathrm{LRL}$ & $<\mathrm{LRL}$ & $<\mathrm{LRL}$ \\
\hline Thiabendazole & ND & ND & ND & ND \\
\hline Trimethoprim & $<\mathrm{LRL}$ & $<\mathrm{LRL}$ & $<\mathrm{LRL}$ & $<\mathrm{LRL}$ \\
\hline Urobilin & ND & ND & ND & ND \\
\hline Warfarin & $<\mathrm{LRL}$ & $<\mathrm{LRL}$ & $<\mathrm{LRL}$ & $<\mathrm{LRL}$ \\
\hline
\end{tabular}


Table 4. Human-health pharmaceutical compound concentrations in water samples collected from Lake Mead, Nevada and Arizona, and Las Vegas Wash, Nevada, October 2000-August 2001-Continued

\begin{tabular}{|c|c|c|c|c|}
\hline \multirow[t]{2}{*}{ Compound } & \multicolumn{2}{|c|}{$\begin{array}{l}\text { Lake Mead at Las Vegas Bay } \\
\text { (site 5) }\end{array}$} & \multirow{2}{*}{$\begin{array}{c}\text { Lake Mead } \\
\text { at Echo Bay } \\
\text { (site 1) } \\
08 / 23 / 01 \\
\end{array}$} & \multirow{2}{*}{$\begin{array}{c}\text { Lake Mead } \\
\text { near historic } \\
\text { confluence of } \\
\text { Colorado and } \\
\text { Virgin Rivers } \\
\text { (site 2) } \\
08 / 23 / 01\end{array}$} \\
\hline & 03/01/01 & 03/01/01 & & \\
\hline Acetaminophen & $0.006 \mathrm{e}$ & $<\mathrm{LRL}$ & $<\mathrm{LRL}$ & $<\mathrm{LRL}$ \\
\hline Amoxicillin & ND & ND & ND & ND \\
\hline Azithromycin & ND & ND & ND & ND \\
\hline Caffeine & 0.027 & $0.002 \mathrm{e}$ & $0.006 \mathrm{e}$ & 0.079 \\
\hline Carbamazepine & ND & ND & ND & ND \\
\hline Cephalexin & ND & ND & ND & ND \\
\hline Cimetidine & $<\mathrm{LRL}$ & $<\mathrm{LRL}$ & $<\mathrm{LRL}$ & $<\mathrm{LRL}$ \\
\hline Clarithromycin & ND & ND & ND & ND \\
\hline Codeine & $<\mathrm{LRL}$ & $<\mathrm{LRL}$ & $<\mathrm{LRL}$ & $<\mathrm{LRL}$ \\
\hline Cotinine & $<\mathrm{LRL}$ & $<\mathrm{LRL}$ & $0.003 \mathrm{e}$ & $0.004 \mathrm{e}$ \\
\hline Dehydronifedipine & $<\mathrm{LRL}$ & $<\mathrm{LRL}$ & $<\mathrm{LRL}$ & $<\mathrm{LRL}$ \\
\hline Digoxigenin & $<\mathrm{LRL}$ & $<\mathrm{LRL}$ & $<\mathrm{LRL}$ & $<\mathrm{LRL}$ \\
\hline Digoxin & $<\mathrm{LRL}$ & $<\mathrm{LRL}$ & $<\mathrm{LRL}$ & $<\mathrm{LRL}$ \\
\hline Diltiazem & $<\mathrm{LRL}$ & $<\mathrm{LRL}$ & $<\mathrm{LRL}$ & $<\mathrm{LRL}$ \\
\hline 1,7-dimethylxanthine & 0.037 & 0.020 & $<\mathrm{LRL}$ & 0.018 \\
\hline Diphenhydramine & ND & ND & ND & ND \\
\hline Enalaprilat & $<\mathrm{LRL}$ & $<\mathrm{LRL}$ & $<\mathrm{LRL}$ & $<\mathrm{LRL}$ \\
\hline Erythromycin & $<\mathrm{LRL}$ & $<\mathrm{LRL}$ & $<\mathrm{LRL}$ & $<\mathrm{LRL}$ \\
\hline Fluoxetine & $<\mathrm{LRL}$ & $<\mathrm{LRL}$ & $<\mathrm{LRL}$ & $<\mathrm{LRL}$ \\
\hline Furosemide & ND & ND & ND & ND \\
\hline Gemfibrozil & $<\mathrm{LRL}$ & $<\mathrm{LRL}$ & $<\mathrm{LRL}$ & $<\mathrm{LRL}$ \\
\hline Ibuprofen & $<\mathrm{LRL}$ & $<\mathrm{LRL}$ & $<\mathrm{LRL}$ & $<\mathrm{LRL}$ \\
\hline Lisinopril & ND & ND & ND & ND \\
\hline Metformin & $<\mathrm{LRL}$ & $<\mathrm{LRL}$ & $<\mathrm{LRL}$ & $<\mathrm{LRL}$ \\
\hline Miconazole & ND & ND & ND & ND \\
\hline Paroxetine metabolite & $<\mathrm{LRL}$ & $<\mathrm{LRL}$ & $<\mathrm{LRL}$ & $<\mathrm{LRL}$ \\
\hline Ranitidine & $<\mathrm{LRL}$ & $<\mathrm{LRL}$ & $<\mathrm{LRL}$ & $<\mathrm{LRL}$ \\
\hline Salbutamol (albuterol) & $<\mathrm{LRL}$ & $<\mathrm{LRL}$ & $<\mathrm{LRL}$ & $<\mathrm{LRL}$ \\
\hline Sulfamethoxazole & $<\mathrm{LRL}$ & $<\mathrm{LRL}$ & $<\mathrm{LRL}$ & $<\mathrm{LRL}$ \\
\hline Thiabendazole & ND & ND & ND & ND \\
\hline Trimethoprim & $<\mathrm{LRL}$ & $<\mathrm{LRL}$ & $<\mathrm{LRL}$ & $<\mathrm{LRL}$ \\
\hline Urobilin & ND & ND & ND & ND \\
\hline Warfarin & $<\mathrm{LRL}$ & $<\mathrm{LRL}$ & $<\mathrm{LRL}$ & $<\mathrm{LRL}$ \\
\hline
\end{tabular}


Table 4. Human-health pharmaceutical compound concentrations in water samples collected from Lake Mead, Nevada and Arizona, and Las Vegas Wash, Nevada, October 2000-August 2001-Continued

\begin{tabular}{|c|c|c|c|c|}
\hline Compound & $\begin{array}{l}\text { Lake Mead at } \\
\text { Saddle Island } \\
\text { (site 3) }\end{array}$ & $\begin{array}{l}\text { Lake Mead at } \\
\text { Callville Bay near } \\
\text { Callville Point } \\
\text { (site 4) }\end{array}$ & $\begin{array}{l}\text { Lake Mead at } \\
\text { Las Vegas Bay } \\
\text { C-Buoy } \\
\text { (site 5) }\end{array}$ & $\begin{array}{c}\text { Las Vegas Wash } \\
\text { below Lake Las } \\
\text { Vegas } \\
\text { (site 6) }\end{array}$ \\
\hline & 08/22/01 & 08/23/01 & 08/22/01 & $10 / 24 / 00$ \\
\hline Acetaminophen & $<$ LRL & $<\mathrm{LRL}$ & $<$ LRL & $<$ LRL \\
\hline Amoxicillin & ND & ND & ND & ND \\
\hline Azithromycin & ND & ND & ND & ND \\
\hline Caffeine & 0.138 & $0.009 \mathrm{e}$ & 0.046 & 0.130 \\
\hline Carbamazepine & ND & ND & 0.002 & ND \\
\hline Cephalexin & ND & ND & ND & ND \\
\hline Cimetidine & $<\mathrm{LRL}$ & $<\mathrm{LRL}$ & $<\mathrm{LRL}$ & $<\mathrm{LRL}$ \\
\hline Clarithromycin & ND & ND & ND & ND \\
\hline Codeine & $<\mathrm{LRL}$ & $<\mathrm{LRL}$ & $<\mathrm{LRL}$ & $<$ LRL \\
\hline Cotinine & $0.016 \mathrm{e}$ & $0.006 \mathrm{e}$ & $0.011 \mathrm{e}$ & 0.130 \\
\hline Dehydronifedipine & $<\mathrm{LRL}$ & $<\mathrm{LRL}$ & $<$ LRL & $<\mathrm{LRL}$ \\
\hline Digoxigenin & $<\mathrm{LRL}$ & $<\mathrm{LRL}$ & $<\mathrm{LRL}$ & $<\mathrm{LRL}$ \\
\hline Digoxin & $<$ LRL & $<\mathrm{LRL}$ & $<$ LRL & $<$ LRL \\
\hline Diltiazem & $<$ LRL & $<\mathrm{LRL}$ & $<$ LRL & $<$ LRL \\
\hline 1,7-dimethylxanthine & 0.021 & $<\mathrm{LRL}$ & $<\mathrm{LRL}$ & $<$ LRL \\
\hline Diphenhydramine & ND & ND & ND & ND \\
\hline Enalaprilat & $<$ LRL & $<\mathrm{LRL}$ & $<$ LRL & $<$ LRL \\
\hline Erythromycin & $<$ LRL & $<\mathrm{LRL}$ & $<$ LRL & $<$ LRL \\
\hline Fluoxetine & $<\mathrm{LRL}$ & $<\mathrm{LRL}$ & $<\mathrm{LRL}$ & $<$ LRL \\
\hline Furosemide & ND & ND & ND & ND \\
\hline Gemfibrozil & $<\mathrm{LRL}$ & $<\mathrm{LRL}$ & $<$ LRL & $<$ LRL \\
\hline Ibuprofen & $<\mathrm{LRL}$ & $<\mathrm{LRL}$ & $<\mathrm{LRL}$ & $<$ LRL \\
\hline Lisinopril & ND & ND & ND & ND \\
\hline Metformin & $<\mathrm{LRL}$ & $<\mathrm{LRL}$ & $<\mathrm{LRL}$ & $<\mathrm{LRL}$ \\
\hline Miconazole & ND & ND & ND & ND \\
\hline Paroxetine metabolite & $<$ LRL & $<\mathrm{LRL}$ & $<\mathrm{LRL}$ & $<$ LRL \\
\hline Ranitidine & $<\mathrm{LRL}$ & $<\mathrm{LRL}$ & $<\mathrm{LRL}$ & $<$ LRL \\
\hline Salbutamol (albuterol) & $<$ LRL & $<\mathrm{LRL}$ & $<\mathrm{LRL}$ & $<$ LRL \\
\hline Sulfamethoxazole & 0.030 & $<\mathrm{LRL}$ & $0.006 \mathrm{e}$ & $<\mathrm{LRL}$ \\
\hline Thiabendazole & $\mathrm{ND}$ & $\mathrm{ND}$ & $\mathrm{ND}$ & ND \\
\hline Trimethoprim & $<\mathrm{LRL}$ & $<\mathrm{LRL}$ & $<\mathrm{LRL}$ & $<$ LRL \\
\hline Urobilin & ND & ND & ND & ND \\
\hline Warfarin & $<\mathrm{LRL}$ & $<\mathrm{LRL}$ & $<\mathrm{LRL}$ & $<\mathrm{LRL}$ \\
\hline
\end{tabular}


Table 4. Human-health pharmaceutical compound concentrations in water samples collected from Lake Mead, Nevada and Arizona, and Las Vegas Wash, Nevada, October 2000-August 2001-Continued

\begin{tabular}{|c|c|c|c|c|}
\hline \multirow[t]{2}{*}{ Compound } & \multicolumn{4}{|c|}{$\begin{array}{c}\text { Las Vegas Wash below Lake Las Vegas } \\
\text { (site 6) }\end{array}$} \\
\hline & $12 / 19 / 00$ & $03 / 04 / 01$ & $06 / 05 / 01$ & $08 / 24 / 01$ \\
\hline Acetaminophen & $<\mathrm{LRL}$ & 0.026 & $<\mathrm{LRL}$ & $<\mathrm{LRL}$ \\
\hline Amoxicillin & ND & ND & ND & ND \\
\hline Azithromycin & ND & ND & ND & ND \\
\hline Caffeine & 0.090 & 0.040 & 0.056 & 0.020 \\
\hline Carbamazepine & 0.064 & 0.052 & 0.140 & 0.087 \\
\hline Cephalexin & ND & ND & ND & ND \\
\hline Cimetidine & 0.024 & 0.063 & $<\mathrm{LRL}$ & $<\mathrm{LRL}$ \\
\hline Clarithromycin & ND & 0.003 & ND & ND \\
\hline Codeine & $<\mathrm{LRL}$ & $<\mathrm{LRL}$ & $0.053 \mathrm{e}$ & $<\mathrm{LRL}$ \\
\hline Cotinine & $<\mathrm{LRL}$ & $0.014 \mathrm{e}$ & $0.019 \mathrm{e}$ & 0.046 \\
\hline Dehydronifedipine & $0.0004 \mathrm{e}$ & 0.010 & $0.004 \mathrm{e}$ & $0.003 \mathrm{e}$ \\
\hline Digoxigenin & $<\mathrm{LRL}$ & $<\mathrm{LRL}$ & $<\mathrm{LRL}$ & $<\mathrm{LRL}$ \\
\hline Digoxin & $<\mathrm{LRL}$ & $<\mathrm{LRL}$ & $<\mathrm{LRL}$ & $<\mathrm{LRL}$ \\
\hline Diltiazem & $<\mathrm{LRL}$ & $<\mathrm{LRL}$ & $0.007 \mathrm{e}$ & $<\mathrm{LRL}$ \\
\hline 1,7-dimethylxanthine & $<\mathrm{LRL}$ & $<\mathrm{LRL}$ & 0.021 & $<\mathrm{LRL}$ \\
\hline Diphenhydramine & ND & ND & ND & ND \\
\hline Enalaprilat & $<\mathrm{LRL}$ & $<\mathrm{LRL}$ & $<\mathrm{LRL}$ & $<\mathrm{LRL}$ \\
\hline Erythromycin & 0.097 & $<\mathrm{LRL}$ & 0.184 & 0.120 \\
\hline Fluoxetine & $<\mathrm{LRL}$ & $<\mathrm{LRL}$ & $<\mathrm{LRL}$ & $<\mathrm{LRL}$ \\
\hline Furosemide & ND & ND & ND & ND \\
\hline Gemfibrozil & $<\mathrm{LRL}$ & $<\mathrm{LRL}$ & $<\mathrm{LRL}$ & $<\mathrm{LRL}$ \\
\hline Ibuprofen & $<\mathrm{LRL}$ & $<\mathrm{LRL}$ & $<\mathrm{LRL}$ & $<\mathrm{LRL}$ \\
\hline Lisinopril & ND & ND & ND & ND \\
\hline Metformin & $<\mathrm{LRL}$ & $<\mathrm{LRL}$ & $<\mathrm{LRL}$ & $<\mathrm{LRL}$ \\
\hline Miconazole & ND & ND & ND & ND \\
\hline Paroxetine metabolite & $<\mathrm{LRL}$ & $<\mathrm{LRL}$ & $<\mathrm{LRL}$ & $<\mathrm{LRL}$ \\
\hline Ranitidine & $<\mathrm{LRL}$ & $<\mathrm{LRL}$ & $<\mathrm{LRL}$ & $<\mathrm{LRL}$ \\
\hline Salbutamol (albuterol) & $<\mathrm{LRL}$ & $<\mathrm{LRL}$ & $<\mathrm{LRL}$ & $<\mathrm{LRL}$ \\
\hline Sulfamethoxazole & 0.149 & 0.200 & 0.073 & $<\mathrm{LRL}$ \\
\hline Thiabendazole & ND & ND & ND & ND \\
\hline Trimethoprim & 0.098 & 0.065 & 0.015 & $<\mathrm{LRL}$ \\
\hline Urobilin & ND & ND & ND & ND \\
\hline Warfarin & $<\mathrm{LRL}$ & $<\mathrm{LRL}$ & $<\mathrm{LRL}$ & $<\mathrm{LRL}$ \\
\hline
\end{tabular}


Table 4. Human-health pharmaceutical compound concentrations in water samples collected from Lake Mead, Nevada and Arizona, and Las Vegas Wash, Nevada, October 2000-August 2001-Continued

\begin{tabular}{|c|c|c|c|}
\hline \multirow{2}{*}{ Compound } & $\begin{array}{c}\text { Las Vegas } \\
\text { Wash below } \\
\text { Lake Las }\end{array}$ & \multicolumn{2}{|c|}{ Equipment blank } \\
\hline & $08 / 24 / 01$ & 03/04/01 & $08 / 24 / 01$ \\
\hline Acetaminophen & $<\mathrm{LRL}$ & $<\mathrm{LRL}$ & $<\mathrm{LRL}$ \\
\hline Amoxicillin & ND & ND & ND \\
\hline Azithromycin & ND & ND & ND \\
\hline Caffeine & $<\mathrm{LRL}$ & $0.004 \mathrm{e}$ & 0.040 \\
\hline Carbamazepine & 0.032 & ND & ND \\
\hline Cephalexin & ND & ND & ND \\
\hline Cimetidine & $<\mathrm{LRL}$ & $<\mathrm{LRL}$ & $<\mathrm{LRL}$ \\
\hline Clarithromycin & ND & ND & ND \\
\hline Codeine & $<\mathrm{LRL}$ & $<\mathrm{LRL}$ & $<\mathrm{LRL}$ \\
\hline Cotinine & 0.030 & $<\mathrm{LRL}$ & $<\mathrm{LRL}$ \\
\hline Dehydronifedipine & $0.005 \mathrm{e}$ & $<\mathrm{LRL}$ & $<\mathrm{LRL}$ \\
\hline Digoxigenin & $<\mathrm{LRL}$ & $<\mathrm{LRL}$ & $<\mathrm{LRL}$ \\
\hline Digoxin & $<\mathrm{LRL}$ & $<\mathrm{LRL}$ & $<\mathrm{LRL}$ \\
\hline Diltiazem & $<\mathrm{LRL}$ & $<\mathrm{LRL}$ & $<\mathrm{LRL}$ \\
\hline 1,7-dimethylxanthine & $0.008 \mathrm{e}$ & $<\mathrm{LRL}$ & $0.001 \mathrm{e}$ \\
\hline Diphenhydramine & ND & ND & ND \\
\hline Enalaprilat & $<\mathrm{LRL}$ & $<\mathrm{LRL}$ & $<\mathrm{LRL}$ \\
\hline Erythromycin & $<\mathrm{LRL}$ & $<\mathrm{LRL}$ & $<\mathrm{LRL}$ \\
\hline Fluoxetine & $<\mathrm{LRL}$ & $<\mathrm{LRL}$ & $<\mathrm{LRL}$ \\
\hline Furosemide & ND & ND & ND \\
\hline Gemfibrozil & $<\mathrm{LRL}$ & $<\mathrm{LRL}$ & $<\mathrm{LRL}$ \\
\hline Ibuprofen & $<\mathrm{LRL}$ & $<\mathrm{LRL}$ & $<\mathrm{LRL}$ \\
\hline Lisinopril & ND & ND & ND \\
\hline Metformin & $<\mathrm{LRL}$ & $<\mathrm{LRL}$ & $<\mathrm{LRL}$ \\
\hline Miconazole & ND & ND & ND \\
\hline Paroxetine metabolite & $<\mathrm{LRL}$ & $<\mathrm{LRL}$ & $<\mathrm{LRL}$ \\
\hline Ranitidine & $<\mathrm{LRL}$ & $<\mathrm{LRL}$ & $<\mathrm{LRL}$ \\
\hline Salbutamol (albuterol) & $<\mathrm{LRL}$ & $<\mathrm{LRL}$ & $<\mathrm{LRL}$ \\
\hline Sulfamethoxazole & $<\mathrm{LRL}$ & $<\mathrm{LRL}$ & $<\mathrm{LRL}$ \\
\hline Thiabendazole & ND & ND & ND \\
\hline Trimethoprim & $<\mathrm{LRL}$ & $<\mathrm{LRL}$ & $<\mathrm{LRL}$ \\
\hline Urobilin & ND & ND & ND \\
\hline Warfarin & $<\mathrm{LRL}$ & $<\mathrm{LRL}$ & $<\mathrm{LRL}$ \\
\hline
\end{tabular}


Lake Mead at Echo Bay (March 2001; site 1)
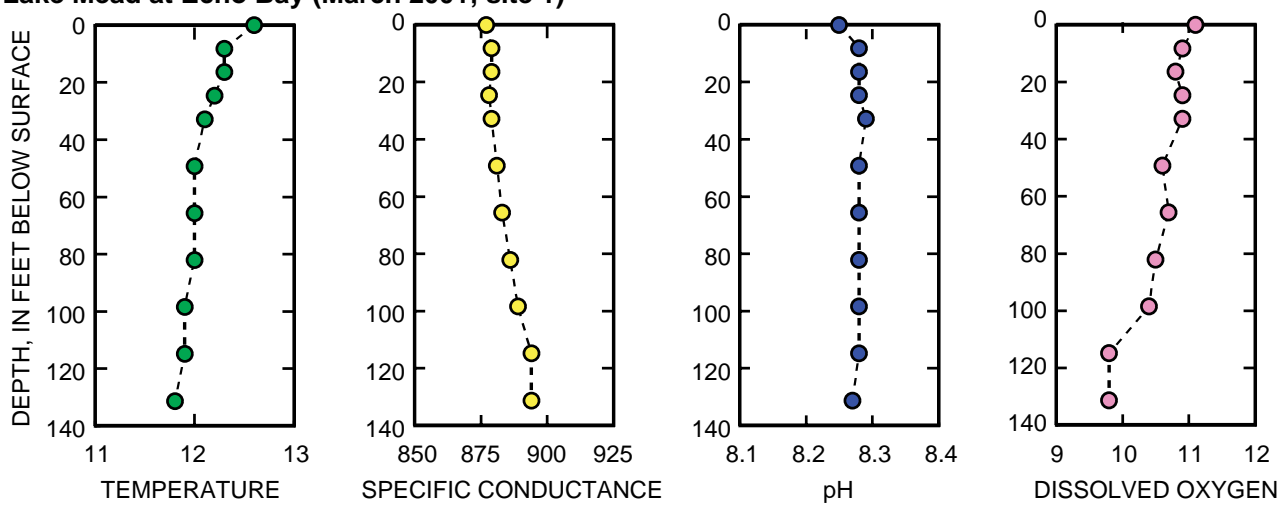

Lake Mead at Echo Bay (August 2001; site 1)
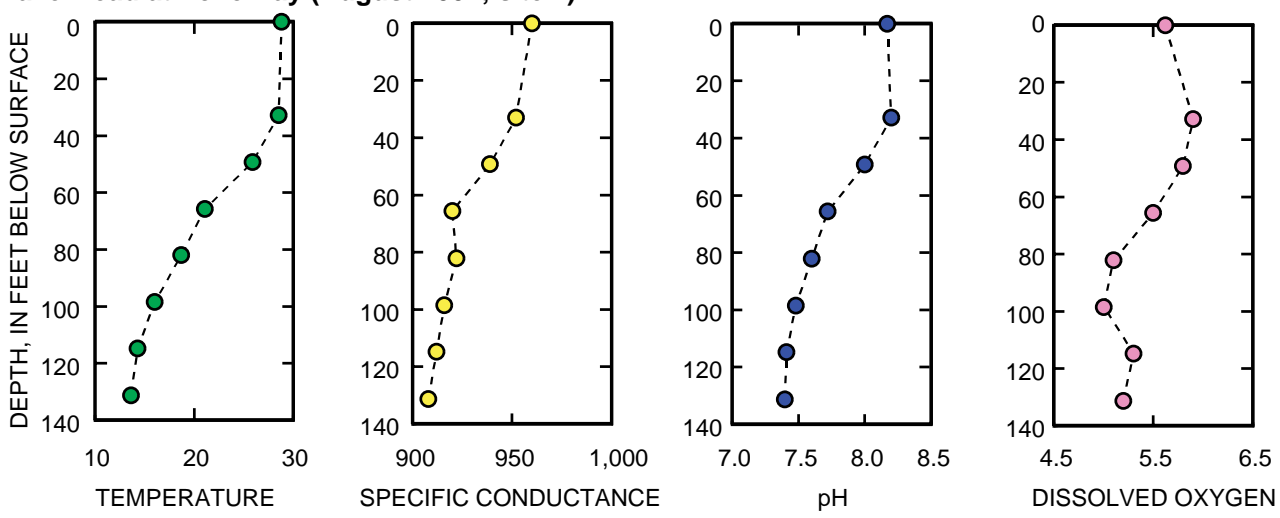

Lake Mead near historic confluence of Colorado and Virgin Rivers (March 2001; site 2)
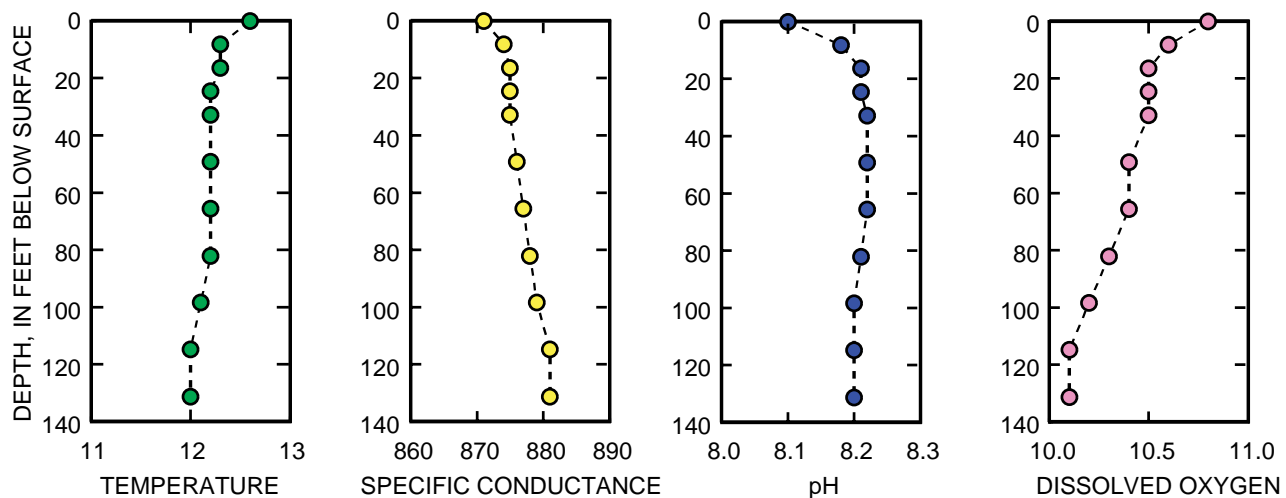

Lake Mead near historic confluence of Colorado and Virgin Rivers (August 2001; site 2)
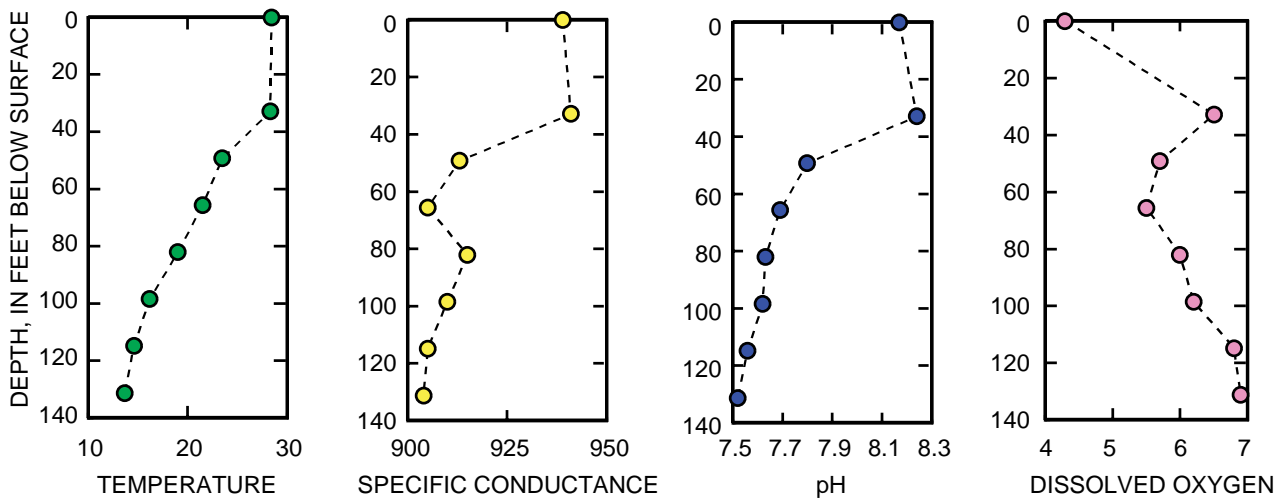

Figure 4. Physical properties measured at sample-collection sites for analyses of human-health pharmaceutical coumpounds, Lake Mead, Nevada and Arizona, and Las Vegas Wash, Nevada, October 2000-August 2001. See figure 1 for site location. 
Lake Mead near Saddle Island (March 2001; site 3)
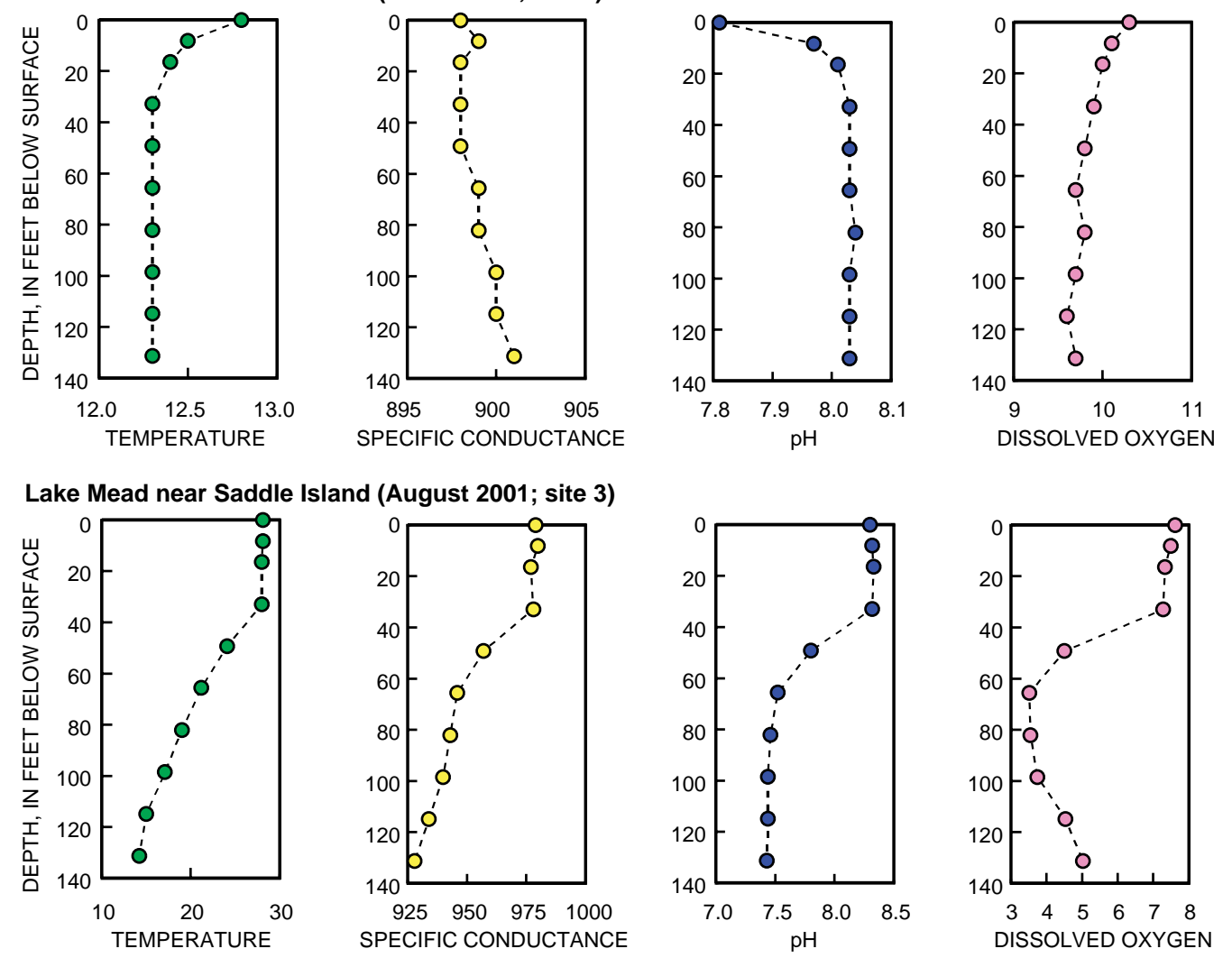

Lake Mead at Callville Bay near Callville Point (March 2001; site 4)
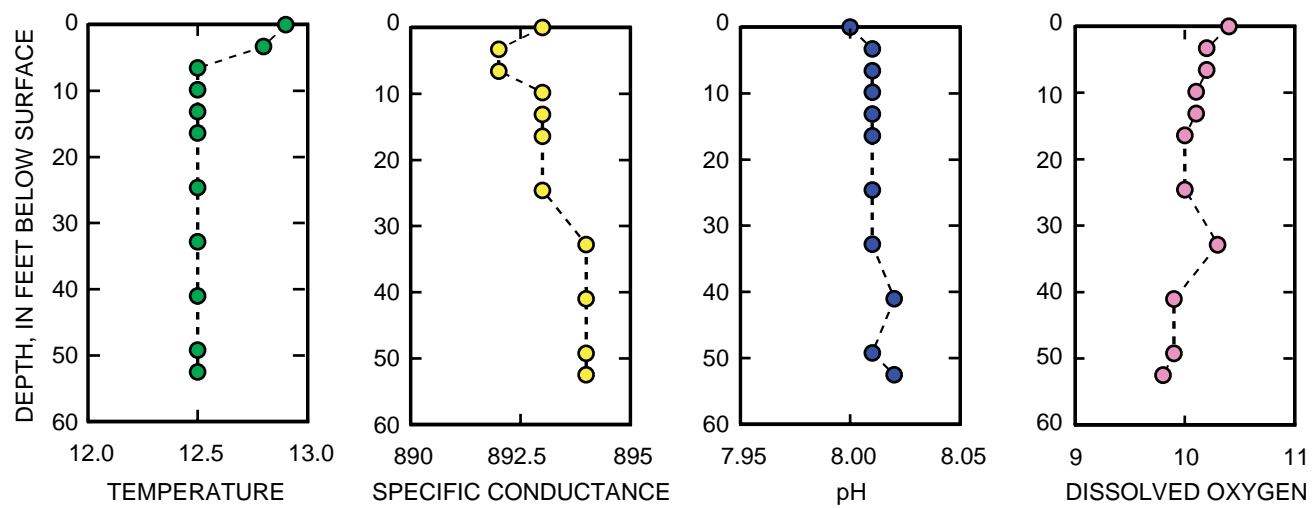

Lake Mead at Callville Bay near Callville Point (August 2001; site 4)
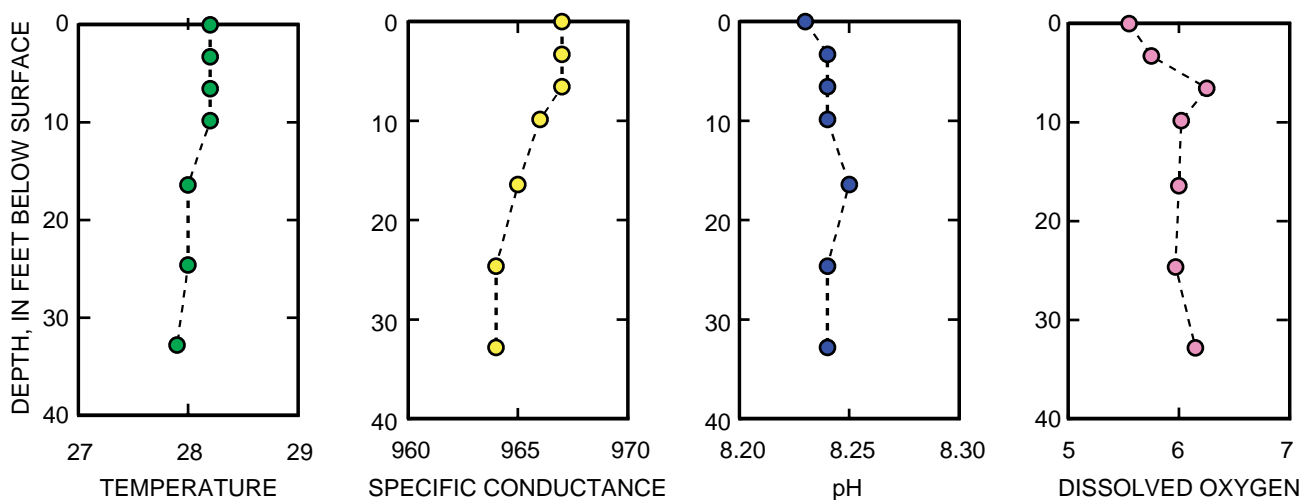

Figure 4. Continued. 

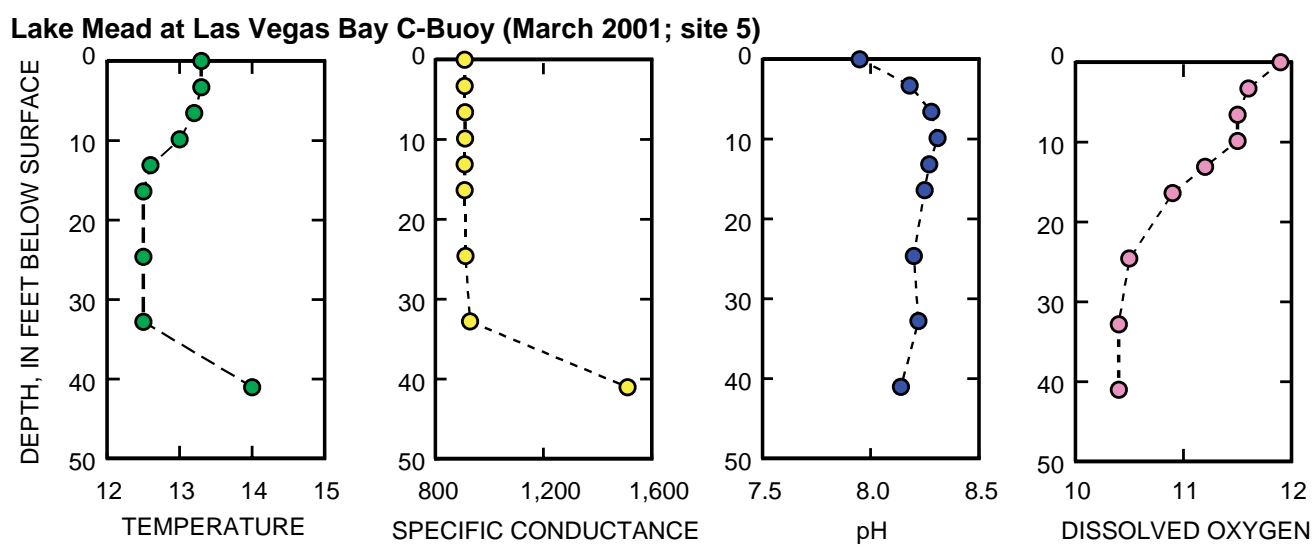

Lake Mead at Las Vegas Bay C-Buoy (August 2001; site 5)
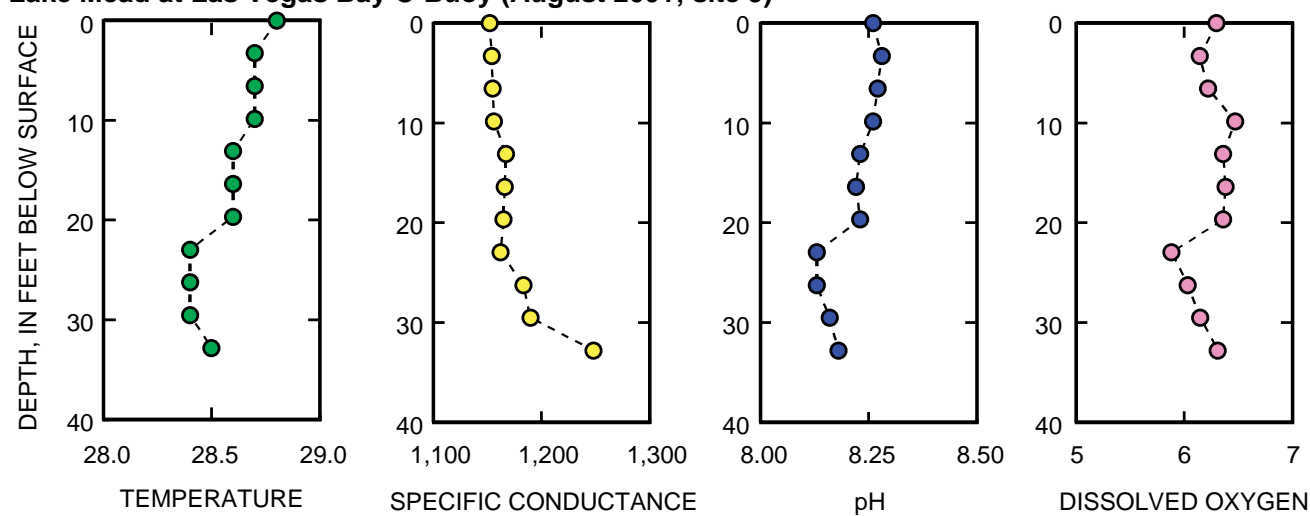

Figure 4. Continued.

Table 5. Physical properties measured concurrently with water samples collected for analyses of human-health pharmaceutical compounds, Las Vegas Wash below Lake Las Vegas, Nevada, October 2000-August 2001

[Abbreviation: $\mu \mathrm{S} / \mathrm{cm}$, microsiemens per centimeter at 25 degrees Celsius]

\begin{tabular}{ccccc}
\hline Date & $\begin{array}{c}\text { Water } \\
\text { temperature, } \\
\text { in degrees } \\
\text { Celsius }\end{array}$ & $\begin{array}{c}\text { Specific } \\
\text { conductance, } \\
\text { in } \mu \mathbf{S} / \mathbf{c m}\end{array}$ & $\begin{array}{c}\mathbf{p H}, \\
\text { in standard } \\
\text { units }\end{array}$ & $\begin{array}{c}\text { Dissolved } \\
\text { oxygen, } \\
\text { in milligrams } \\
\text { per liter }\end{array}$ \\
\hline $10 / 24 / 00$ & 22.5 & 2,930 & 8.10 & 8.0 \\
$12 / 19 / 00$ & 16.5 & 2,800 & 8.00 & 9.3 \\
$03 / 04 / 01$ & 12.0 & 2,810 & 8.00 & 7.2 \\
$06 / 05 / 01$ & 23.0 & 2,940 & 8.20 & 8.4 \\
$08 / 24 / 01$ & 25.0 & 2,320 & 8.05 & 6.3 \\
\hline
\end{tabular}


more samples collected from Las Vegas Wash. Penicillin-based antibiotics (such as amoxicillin) were not detected in any water samples. Penicillin-based antibiotics are known to rapidly degrade in wastewater treatment systems and aquatic systems because the compounds are susceptible to hydrolysis (Daughton and Ternes, 1999). Hirsch and others (1999) and Kolpin and others (2002) reported similar results for penicillin-based antibiotics in separate studies conducted in Germany and the United States, respectively. Carbamazepine and dehydronifedipine were detected in five of six water samples collected from Las Vegas Wash (table 3). Less frequently detected compounds were acetaminophen, cimetidine, codeine, and diltiazem.

Fewer human-health pharmaceutical compounds were detected in water samples collected from Lake Mead than from Las Vegas Wash. Non-prescription compounds were detected most frequently. Caffeine was detected in all water samples collected from Lake Mead. Acetaminophen, cotinine, and 1,7-dimethylxanthine also were detected. Carbamazepine and sulfamethoxazole were the only prescription-pharmaceutical compounds detected in water samples from Lake Mead. Carbamazepine was detected in one sample collected from Las Vegas Bay (site 5; fig. 1, table 2 ). Sulfamethoxazole was detected in one sample collected from Las Vegas Bay and in one sample collected near Saddle Island (site 3). LaBounty and Horn (1997) identified a density-current plume of degraded water quality that is discharged by Las Vegas Wash into Las Vegas Bay and other parts of Boulder Basin (fig. 1) which could explain pharmaceutical compounds at these sites. The decreased number of pharmaceutical compounds detected in Lake Mead water samples probably can be attributed to dilution of Las Vegas Wash discharge as it mixes with lake water. Other processes such as chemical dispersion, sediment sorption, biouptake by aquatic organisms, and chemical degradation also may reduce the number and concentrations of detected compounds.

Water samples from Lake Mead were collected in March 2001 and August 2001 to evaluate potential seasonal differences in the occurrence and concentrations of compounds. Three compounds (acetaminophen, caffeine, and 1,7-dimethylxanthine) were detected in water samples collected in March 2001 whereas five compounds (caffeine, carbamazepine, cotinine, 1,7dimethylxanthine, and sulfamethoxazole) were detected in August 2001. Higher water temperatures and associated greater biological activity may signifi- cantly increase degradation or biological uptake of some compounds. Acetaminophen was detected in some water samples collected in March but not in the August samples. Most antibiotic compounds (clarithromycin, erythromycin, sulfamethoxazole, and trimethoprim) were detected in water samples collected from Las Vegas Wash in months with cool to moderate water temperatures (December, March, and June); erythromycin was the only antibiotic compound detected in water samples collected in months with warm to moderate temperatures (August and October). Compounds used as analgesics and anti-inflammatories (such as acetaminophen) tend to readily biodegrade or photodegrade in the environment and many antibiotics can readily bioaccumulate in aquatic organisms (HallingSorensen and others, 1998; Daughton and Ternes, 1999). In Lake Mead, caffeine concentrations were higher in samples collected in August than in March. This increase may reflect anthropogenic impacts during summer months when recreational use of Lake Mead is greatest.

\section{REFERENCES CITED}

Barnes, K.K., Kolpin, D.W., Meyer, M.T., Thurman, E.M., Furlong, E.T., Zaugg, S.D., and Barber, L.B., 2002, Water-quality data for pharmaceuticals, hormones, and other organic wastewater contaminants in U.S. streams, 1999-2000: U.S. Geological Survey Open-File Report 02-94, variable pagination.

Blomquist, J.D., Denis, J.M., Cowles, J.L., Hetrick, J.A., Jones, R.D., Birchfield, N.B., 2001, Pesticides in selected water-supply reservoirs and finished drinking water, 1999-2000: Summary of results from a pilot monitoring program: U.S. Geological Survey OpenFile Report 01-456, 65 p.

Buszka, P.M., Barber II, L.B., Schroeder, M.P., and Becker, L.D., 1994, Organic compounds downstream from a treated-wastewater discharge near Dallas, Texas, March 1987: U.S. Geological Survey Water-Resources Investigations Report 93-4194, 19 p.

Covay, K.J., Banks, J.M., Bevans, H.E., and Watkins, S.A., 1996, Environmental and hydrologic settings of the Las Vegas Valley area and the Carson and Truckee River Basins, Nevada and California: U.S. Geological Survey Water-Resources Investigations Report 96-4087, 72 p.

Daughton, C.G., and Ternes, T.A., 1999, Pharmaceuticals and personal care products in the environment-agents of subtle change: Environmental Health Perspectives, v. 107, supplement 6, p. 907-938. 
Halling-Sorensen, B., Nielson, S.N., Lanzky, P.F., Ingerslev, F., Lutzhoft, H.C., and Jorgensen, S.E., 1998, Occurrence, fate, and effects of pharmaceuticals substances in the environment - a review: Chemosphere-Chemistry, Biology, and Toxicology as Related to Environmental Problems, v. 36, no. 2, p. 357-391.

Hignite, C., and Azarnoff, D.L., 1977, Drugs and drug metabolites as environmental contaminants: chlorophenoxyisobutyrate and salicylic acid in sewage water effluent: Life Sciences, v. 20, no. 2, p. 337-341.

Hirsch, R., Ternes, T.A., Haberer, K., and Kratz, K.L., 1999, Occurrence of antibiotics in the aquatic environment: Science of the Total Environment, v. 225, no. 1-2, p. 109-118.

Kolpin, D.W., Furlong, E.T., Meyer, M.T., Thurman, E.M., Zaugg, S.D., Barber, L.B., and Buxton, H.T., 2002, Pharmaceuticals, hormones, and other organic wastewater contaminants in U.S. streams, 1999-2000: A national reconnaissance: Environmental Science and Technology, v. 36, no. 6, p. 1202-1211

LaBounty, J.F., and Horn, M.J., 1997, The influence of drainage from the Las Vegas Valley on the limnology of Boulder Basin, Lake Mead, Arizona-Nevada: Journal of Lake and Reservoir Management, v. 13, no. 2, p. 95108.

Las Vegas Valley Water District, 2002, Narrative summary: Website accessed at <http://www.lvvwd.org/> on May 29, 2002.
Rogers, I.H., Birtwell, I.K., and Kruzynski, G.M., 1986, Organic extractables in municipal waste water: Vancouver, British Columbia, Water Pollution Research Journal Canada, v. 21, no. 2, p. 187-204.

Seiler, R.L., Zaugg, S.D., Thomas, J.M., and Howcroft, D.L., 1999, Caffeine and pharmaceuticals as indicators of waste water contamination in wells: Ground Water, v. 37, no. 3, p. 405-410.

Snyder, S.A., Keith, T.L., Verbrugge, D.A., Snyder, E.M., Gross, T.S., Kannan, K., and Giesy, J.P., 1999, Analytical methods for detection of selected estrogenic compounds in aqueous mixtures: Environmental Science and Technology, v. 33, no. 16, p. 2814-2820.

U.S. Department of the Interior, 1999, Quality of water: Colorado River Basin, Progress Report no. 19, variable pagination.

Wilde, F.D., Radtke, D.B., Gibs, J., and Iwatsubo, R.T., 1998, National field manual for the collection of waterquality data; field measurements: U.S. Geological Survey Techniques of Water-Resources Investigation, book 9, chap. A6 (variously paginated). 